\title{
PENERAPAN MANAJEMEN KONSTRUKSI DALAM PELAKSANAAN KONSTRUKSI
}

\author{
Ummi Chasanah $^{1 *}$ dan Sulistyowati ${ }^{2}$ \\ ${ }^{1,2}$ Program Studi D3 Teknik Sipil Fakultas Teknik Universitas Pandanaran \\ Jl. Banjarsari Barat No. 1 Tembalang Semarang 50275 \\ Email* : chasanah_ummi@yahoo.com
}

\begin{abstract}
ABSTRAK
Konstruksi merupakan rangkaian yang hanya sekali dilaksanakan, dengan adanya batasan jangka waktu. Sehingga dalam kegiatan tersebut, terdapat suatu proses untuk dapat mengolah sumber daya manusia maupun sumber daya lain yang terlibat dalam pelaksanaan konstruksi menjadi hasil dari suatu kegiatan yang dapat dimanfaatkan. Dengan banyaknya pihak yang terlibat dalam konstruksi maka berpotensi terjadi adanya konflik yang besar pula sehingga disampaikan bahwa pelaksanaan konstruksi mengandung konflik yang cukup tinggi. Dunia konstruksi juga mengklasifikasikan jenis konstruksi menjadi 3 (tiga) bagian konstruksi besar antara lain: konstruksi gedung, konstruksi teknik, dan konstruksi manufaktur.

Karakter proyek konstruksi dapat dilihat dengan 3 dimensi yaitu bahwa konstruksi dapat bersifat unik, adanya keterlibatan sejumlah sumber daya, dan konstruksi tersebut membutuhkan adalah organisasi. Dunia konstruksi membagi dan mengklasifikasikan lima sumber daya untuk membangun suatu proyek konstruksi dan pada saat mengatur proyek dengan menerapkan kelima unsur $\mathrm{M}$ yaitu manpower (tenaga kerja), machiners (alat dan peralatan), material (bahan bangunan), money (uang), dan method (metode). Proyek konstruksi dalam pelaksanaannya harus memperhatikan 3 hal yaitu kualitas/mutu, waktu, dan biaya yang telah dipersyaratkan dalam perencanaan sebelumnya.
\end{abstract}

Kata Kunci : Konstruksi, Manajemen, Mutu, Waktu, Biaya

\section{PENDAHULUAN}

Pengembangan pembangunan di Indonesia dengan berbagai bidang yang ada. Pelaksanaan pembangunan konstruksi yang selalu melibatkan berbagai pihak, antara lain penyedia jasa, dalam hal ini kontraktor. Dengan kontrak pelaksanaan pembangunan dapat dilaksanakan secara efektif, efisien, dan dapat dipertanggungjawabkan, baik segi kualitas dan administrasi. Secara pelaksanaan konstruksi yang bersifat dinamis dengan menunjukkan suatu perubahan baik jenis maupun jumlahnya.

Pelaksanaan konstruksi merupakan salah satu industri ekonomi nasional yang berhubungan dengan persiapan lahan dan pembangunan, percepatan, dan perbaikan bangunan struktur, struktur, dan properti lainnya. Berdasarkan hal tersebut, industri konstruksi merupakan salah satu industri yang berkembang di seluruh dunia.

Pertumbuhan industri konstruksi akan seiring sejalan dengan pertumbuhan ekonomi suatu Negara. Agar pelaksanaan konstruksi dapat berjalan dengan lancar dan selesai tepat waktu, maka diperlukan pengaturan manajemen konstruksi dengan baik. Manajemen konstruksi dapat mengatur kapan konstruksi tersebut dilaksanakan dan kapan selesai dengan perhitungan waktu yang ditentukan. Hal ini dilakukan untuk menghindari kemungkinan terjadi kemunduran waktu dan penambahan biaya

\section{TUJUAN}

Mendapatkan cara yang tepat dalam pelaksanaan suatu konstruksi dengan pencapaian 
hasil yang maksimal mengenai tepat waktu, tepat mutu dan tepat biaya.

\section{TINJAUAN PUSTAKA}

Menurut Ervianto (2005) manajemen konstruksi adalah perencanaan, pelaksanaan, pengendalian dan koordinasi suatu proyek konstruksi mulai dari gagasan awal sampai proyek konstruksi tersebut berakhir untuk menjamin pelaksanaan proyek secara tepat waktu, tepat mutu dan tepat biaya. Sehingga manajemen konstruksi di kelola oleh sekelompok orang yang memiliki tugas dan tanggung jawab yang berbeda - beda. Berikut merupakan pihak-pihak yang terlibat dalam proyek konstruksi.

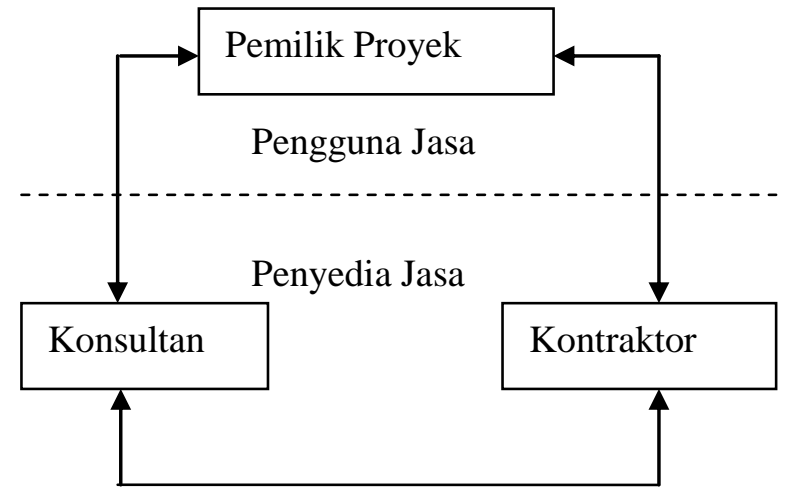

Gambar 1: Pihak-pihak yang terlibat dalam proyek konstruksi (Ervianto, 2005).

Menurut Husen (2010), mengenai manajemen yang harus diperhatikan antara lain :

a. Perencanaan (Planning)

Pada perencanaan tercantum adanya sasaran, tujuan yang dicapai hingga kebijakankebijakan lain untuk menunjang keberhasilan. Sehingga dalam perencanaan perlu dikerjakan secara, cermat, dan meminimalkan risiko kesalahan kerja, walaupun perencanaan tersebut terus disempurnakan sesuai dengan perubahan dan perkembangan yang terjadi pada proses pelaksanaan.

b. Pengorganisasian (Organizing)

Kegiatan ini melingkupi pengelompokan dari jenis-jenis pekerjaan (work breakdown structure), menentukan personil yang akan bertanggung jawab dalam pekerjaan tersebut. Sehingga perlu adanya struktur organisasi yang disesuaikan dengan kebutuhan pelaksanaan proyek dan kerangka penjabaran yang sesuai dengan keahlian dan kemampuan dari tiap personilnya.

c. Pelaksanaan (Actuating)

Kegiatan ini mengimplementasikan dari perencanaan yang telah ditetapkan dengan melakukan tahapan pekerjaan sesungguhnya secara fisik maupun non fisik sehingga produk akhir sesuai dengan sasaran dan tujuan yang direncanakan.

d. Pengendalian (Controlling)

Kegiatan ini dimaksudkan untuk memastikan mengenai proses dan aturan kerja yang telah ditetapkan dapat dicapai dengan hasil yang maksimal.

Berikut merupakan proses manajemen konstruksi :

\begin{tabular}{|c|c|c|}
\hline Input : & Fungsi : & Output : \\
\hline $\begin{array}{l}\text { Tujuan, } \\
\text { sasaran, } \\
\text { informasi,da } \\
\text { ta, serta } \\
\text { sumber } \\
\text { daya. }\end{array}$ & $\begin{array}{l}\text { Perencanaan, } \\
\text { pengorganisa } \\
\text { sian, } \\
\text { pengendalian } \\
\text {. }\end{array}$ & $\begin{array}{l}\text { Optimasi } \\
\text { kinerja } \\
\text { proyek : } \\
\text { biaya, } \\
\text { mutu, } \\
\text { biaya, K3. }\end{array}$ \\
\hline
\end{tabular}

Gambar 2: Proses Manajemen Konstruksi (Husen, 2010).

Sektor-sektor berbeda dengan pertumbuhan industri konstruksi, menunjukkan pada pertumbuhan yang berbeda di seluruh dunia, seperti :

1. Industri konstruksi menyumbangkan nilai yang sangat besar pada perdapatan perkapita dunia, yaitu sekitar 1/10 dari GDP dunia.

2. Industri konstruksi merupakan industri yang potensial dalam penyerapan tenaga kerja yang besar, yaitu sekitar 7\% dari seluruh tenaga kerja di dunia.

3. Industri konstruksi menyerap $2 / 5$ dari total penyerapan energi di seluruh dunia yang membuat industri ini menjadi sektor terbesar dalam penyerapan energi. 
Industri yang terdiri dari perusahaan besar maupun perusahaan kecil. Dengan berbagai sektor konstruksi yang merupakan industri yang berbeda dengan industri lainnya, maka pembagian jenis konstruksi akan sangat membantu dalam memahami struktur industri ini.

Berikut menurut Widiasanti dan Lenggogeni, (2013), dalam konstruksi dapat dibagi menjadi 2, antara lain :

a. Teknologi konstruksi

Merupakan teknologi konstruksi yang berhubungan dengan metode maupun teknik yang digunakan untuk menempatkan material fisik dan elemen-elemen konstruksi yang lain pada tempatnya di lapangan. Sehingga konstruksi yang ditanyakan merupakan salah satu yang penting yang akan dihadapi manajer konstruksi. Untuk itu setiap metode yang digunakan sangat penting untuk dapat dipertimbangkan keuntungan dan kerugiannya serta metode tersebut agar selalu dapat diperbaharui.

b. Manajemen konstruksi

Manamen konstruksi mengacu bagaimana sumber daya tersebut tersedia untuk dapat membangun suatu konstruksi yang baik bagi manajer, sehingga dapat diaplikasikan dengan baik dalam suatu konstruksi yang dihasilkan. Dalam manajemen konstruksi sumber daya yang diperlukan biasa di sebut dengan $5 \mathrm{M}$, antara lain :

- Manpower (tenaga kerja)

- Machiner (alat dan peralatan)

- Material (bahan bangunan)

- Money (uang)

- Method (metode)

Dengan melibatkan waktu dan mengaplikasikan 5 sumber daya tersebut di atas yang digunakan untuk membangun konstruksi dengan baik dan hasil yang maksimal. Selain sumber daya daya $5 \mathrm{M}$ tersebut juga melibatkan perencanaan baik yang dipertimbangkan dari segi waktu, kualitas, dan biaya yang dianggarkan.

Sehingga seorang manajer adalah bagaimana cara memanfaatkan sumber daya semaksimal mungkin dengan efektif dan efisien dalam kerangka perencanaan waktu, kualitas, dan biaya untuk memenuhi pencapaian tujuan owner. Konsep dasar dari pembangunan konstruksi adalah kemampuan manajer dalam menempatkan sumber daya manusia, peralatan, material, dengan pembiayan biaya terbatas, dan dengan waktu yang telah ditentukan, serta kualitas sesuai dengan yang direncanakan.

Pekerjaan konstruksi selalu dimulai dengan hal sebagai berikut, diantaranya: penyusunan perencanaan, penyusunan jadwal, dan pengendalian yang digunakan untuk mendapatkan hasil sesuai dengan rencana. Sehingga dalam perencanaan konstruksi merupakan suatu proses untuk menentukan tujuan bahkan sasaran dengan keterlibatan pencapaian dari sumber daya.

Sehingga perencanaan yang dibuat dengan baik akan mengikat dan mengarahkan pelaksanaan kegiatan konstruksi untuk memanfaatkan sumber daya yang efektif dan efisien demi mewujudkan sasaran dan tujuan awal.

Penjadwalan konstruksi tersebut merupakan alat untuk menentukan waktu yang diperlukan untuk kegiatan konstruksi dan penyelelesaiannya. Selain itu sebagai alat untuk menentukan kapan konstruksi tersebut dapat dimulai dan kegiatan konstruksi dapat diselesaikan. Ketepatan penjadwalan konstruksi dalam pelaksanaannya sangat berpengaruh agar terhindar dari kerugian timbul. Misalkan terjadi pembengkakan biaya konstruksi karena hal tertentu bahkan bisa berakibat proses penyerahan konstruksi yang mengalami keterlabatan.

Menurut Edwin (1961) menyampaikan bahwa Personnal management is the planning, organizing, directing, and controlling of the prorucement, development, compensation, maintenance, and separation, of human resources, to the end that individual, organization, and societal objectives are accomplished.

Manajemen personalia merupakan perencanaan, pengorganisasian, pengarahan, dan pengendalian, dari pengadaan (Edwin, 2002).

Keterangan

- Stage 1

Feasibility

- Stage 2

Planning and Design

- Stage 3 
Production

- Stage 4

Tunnover and Start Up

Berikut merupakan Siklus Hidup Proyek Konstruksi.

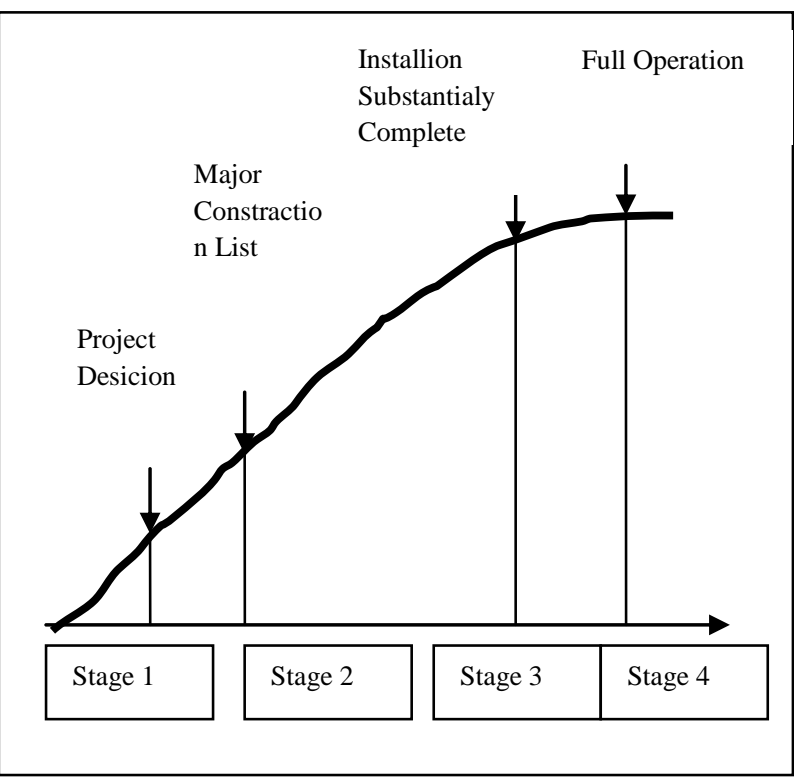

Gambar 3: Siklus Hidup Proyek Konstruksi

\section{METODOLOGI}

Penelitian ini dengan menggunakan metode kualitatif dan kuantitatif. Metode kualitatif digunakan untuk mengetahui hal -hal yang mempengaruhi penerapan manajemen pelaksanakan konstruksi. Sedangkan metode kuantitatif digunakan untuk mengetahui faktor yang menjadi pendukung dan faktor tingkat keuntungan dari manajemen konstruksi.

\section{HASIL DAN PEMBAHASAN}

Pelaksanaan konstruksi dapat berjalan dengan baik jika di dukung dengan manajemen yang baik pula. Sehingga manajemen merupakan kemampuan untuk memperoleh hasil dengan pencapaian tujuan dengan sekelompok orang. Untuk itu manajemen dapat berfungsi sebagai berikut :

1. Perencanaan, merupakan tindakan dalam pengambilan keputusan yang mengandung data/informasi atau asumsi bahkan fakta kegiatan yang akan dipilih dan dilakukan pada masa yang akan datang.

2. Pengorganisasian,merupakan tindakan untuk mempersatukan kumpulan kegiatan manusia, yang mempunyai pekerjaan di bidang masing masing dan saling berhubungan satu sama lain serta adanya tata cara tertentu.

3. Pelaksanaan, merupakan pergerakan orang yang tergabung dalam organisasi agar melakukan kegiatan yang telah ditetapkan/direncanakan dalam planning awal.

4. Penggendalian, merupakan wadah ataupun usaha yang tersimetris dari perusahaan untuk mencapai tujuan dengan cara membandingkan prestasi kerja dengan rencana dan membuat tindakan yang tepat guna mengkoreksi perbedaan yang penting.

Analisis dengan CPM, antara lain sebagai berikut : dalam pelaksanaan konstruksi terdapat beberapa hal tahapan seperti pengurugan tanah, pengadaan material, pemasangan pondasi dan sebagainya. Di setiap tahapan ada durasi waktu, dan mungkin beberapa tahapan dikerjakan dalam waktu yang sama dengan syarat tertentu.

Seandainya pengerjaan suatu tahapan membutuhkan durasi waktu 12 hari kerja dan tahapan tersebut bergeser 3 hari lebih lama. Sehingga tahapan tersebut selesai dalam waktu 13 hari kerja, maka terdapat slack sebesar 3 hari. Dengan demikian setiap tahapan akan ada ES = saat paling awal aktivitas di mulai, $\mathrm{EF}=$ saat paling akhir aktivitas selesai, LS = saat paling lama aktivitas mulai, dan $\mathrm{LF}=$ saat paling akhir aktivitas selesai.

Sehingga kendala yang dihadapi dalam pelaksanaan konstruksi tersebut adalah waktu dan biaya yang diperlukan untuk menyelesaikan konstruksi tersebut. Sedangkan keberhasilan suatu manajemen pelaksanaan konstruksi antara lain :

- Waktu pelaksanaan sesuai dengan kontrak (tepat waktu).

- Biaya sesuai yang direncanakan walaupun tidak sama persis.

- Dapat memenuhi keinginan user sesuai rencana dan memuaskan semua pihak yang terlibat.

Faktor yang menjadi pendukung manajemen konstruksi antara lain : 
- Keterlibatan/peran serta user dalam pelaksanaan konstruksi.

- Pengalaman dari manajer konstruksi.

- Tujuan konstruksi yang jelas.

- Scope yang kecil.

- Estimasi biaya yang sesuai.

Sedangkan keuntungan manajemen konstruksi antara lain :

- Perencanaan yang tepat dan staff yang kompeten.

- Waktu pelaksanaan yang sesuai dengan rencana.

- Biaya yang tidak jauh beda dengan rencana.

- Mutu sesuai dengan rencana.

Di dapat keuntungan memadai dan meningkatnya produktivitas serta terjaganya koordinasi yang antar semua pihak.

\section{SIMPULAN}

Berdasarkan paparan di atas maka dapat disimpulkan sebagai berikut :

1. Manajemen merupakan hal yang sangat penting demi terciptanya pelaksanaan konstruksi dapat berjalan dengan baik, dengan melibatkan $5 \mathrm{M}$ yaitu : manpower (tenaga kerja), machiners (alat dan peralatan), material (bahan bangunan), dan money (uang), serta method (metode).

2. Penerapan manajemen konstruksi mampu mengontrol seluruh kegiatan konstruksi mulai dari awal sampai selesai konstruksi tersebut dan dapat menentukan waktu yang diperlukan serta dapat meminimalisir dana yang digunakan untuk terselesainya konstruksi.

\section{DAFTAR PUSTAKA}

Edwin B. F., 1961, Principles of Personnel Management first edition, McGraw-Hill Book Co, New York.

Edwin B. F., 2002. Personel Management (Manajemen Personalia), Edisi VII Jilid II, Terjemahan Alponso S, Erlangga, Jakarta

Ervianto, W. I., 2005, Manajemen Proyek Konstruksi Edisi 2, CV. Andi Offset, Yogyakarta.

Husen, A., 2010, Manajemen Proyek, CV. Andi Offset, Yogyakarta.
Widiasanti dan Lenggogeni, 2013, Manajemen Konstruksi, PT. Remaja Rosdakarya, Bandung. 